December 2007

\title{
Bactericidal activity of extended 9-glycyl-amido-minocyclines
}

Chang-po Chen

Thomas Jefferson University

Allen R. Zeiger

Thomas Jefferson University

Dr. Eric Wickstrom

Thomas Jefferson University

Follow this and additional works at: https://jdc.jefferson.edu/bmpfp

Part of the Medical Biochemistry Commons

Let us know how access to this document benefits you

\section{Recommended Citation}

Chen, Chang-po; Zeiger, Allen R.; and Wickstrom, Dr. Eric, "Bactericidal activity of extended 9-glycyl-amido-minocyclines" (2007). Department of Biochemistry and Molecular Biology Faculty Papers. Paper 16.

https://jdc.jefferson.edu/bmpfp/16

This Article is brought to you for free and open access by the Jefferson Digital Commons. The Jefferson Digital Commons is a service of Thomas Jefferson University's Center for Teaching and Learning (CTL). The Commons is a showcase for Jefferson books and journals, peer-reviewed scholarly publications, unique historical collections from the University archives, and teaching tools. The Jefferson Digital Commons allows researchers and interested readers anywhere in the world to learn about and keep up to date with Jefferson scholarship. This article has been accepted for inclusion in Department of Biochemistry and Molecular Biology Faculty Papers by an authorized administrator of the Jefferson Digital Commons. For more information, please contact: JeffersonDigitalCommons@jefferson.edu. 


\title{
Bioorganic \& Medicinal Chemistry Letters 18, BMCL-S-07-01245 \\ Bactericidal Activity of Extended 9-Glycyl-Amido-Minocyclines
}

\author{
Chang-po Chen, Allen R. Zeiger, and Eric Wickstrom* \\ Department of Biochemistry \& Molecular Biology \\ Thomas Jefferson University, Philadelphia PA 19107, USA \\ Received July ??, 2007; Accepted September ??, 2007
}

\begin{abstract}
The need for self-protecting polymer or alloy implants resistant to a broad spectrum of bacterial challenges led us to investigate covalent bonding of minocycline (MIN), a tetracycline derivative, to polystyrene beads and to titanium alloy foils by oligoethylene glycol spacers. 9-Hydrazino-acetyl-amido-MIN, and simpler glycylcycline derivatives, retained minimum inhibitory concentration (MIC) against Staphylococcus aureus comparable to MIN. However, PEG-glycyl-amido-MIN showed very low activity. Hence, we coupled 9hydrazino-acetyl-amido-MIN to the aldehyde termini of oligoethylene glycol spacers bonded to polystyrene and titanium alloy surfaces to form acid-releasable hydrazone linkages. 9-Hydrazino-acetyl-amido-MIN was released from the monolayers more rapidly at $\mathrm{pH} 5.0$ than at pH 7.4. (C2007 Elsevier Science Ltd. All rights reserved.
\end{abstract}

Infections are a devastating complication of medical implant devices that cause significant morbidity. The management of infected implants has serious economic implications. For example, in the United States, treatment of 3500-4000 cases of knee and hip infections every year costs an estimated 150 to 200 million dollars ${ }^{1}$. Because of poor vascularity and biofilm formation at the implant sites, such infections have proven difficult to prevent or treat. The local application of antibiotics is a well-known and accepted therapy for such kind of implications ${ }^{2-4}$. Current practice includes antibiotic-impregnated bone cement ${ }^{5}$, and antibioticcontaining coating systems ${ }^{6-8}$. These methods are intended to release antibiotics rapidly and irreversibly, and require a carrier material other than the orthopaedic implant itself to transport the antibiotic materials. Some non-resorbable materials used in the methods even need to be removed after the surgery'.

Because of the combination of their many biocompatible properties, titanium and titanium alloys are frequently applied in a wide variety of biomedical devices ${ }^{10}$. In our initial studies ${ }^{11}$ using fine titanium (Ti) particles which had been aminopropylated ${ }^{12,13}$, we utilized the last resort glycopeptide antibiotic vancomycin (VAN), which acts at the surface of the Gram-positive bacterial cell wall to block peptidoglycan synthesis $^{14,15}$. Hydrophilic bis(ethylene glycol) spacers were coupled to the solid phase $\mathrm{NH}_{2} \mathrm{PrSiO}$-Ti particles, followed by $\mathrm{VAN}^{11}$. The biological results showed that the VAN-modified Ti particles effectively inhibited the growth of $S$. aureus compared with control Ti particles on which the bacteria grew abundantly ${ }^{11}$.

Keywords: antibiotics, biofilms, implants, orthopedics, spacers *Correspondence: Dr. Eric Wickstrom, Department of Biochemistry \& Molecular Biology, Thomas Jefferson University, Philadelphia PA 19107-5541, USA voice: 1-215-955-4578; fax: 1-215-955-4580 email: eric@tesla.jci.tju.edu; website: http://tesla.jci.tju.edu
The strategy was then extended to Ti6Al4V alloy pins, widely used for orthopaedic implants ${ }^{16}$. We found that VAN could be covalently linked to the Ti6Al4V alloy surface on orthopaedic implants, following oxidation ${ }^{17}$. Covalently bound VAN was retained on the surface for an extended period of time and retained significant antibiotic activity ${ }^{18}$.

Most implant infections are caused by Gram-positive bacteria $^{19}$, but some are caused by Gram-negative bacteria, which are susceptible to broad-spectrum antibacterial agents such as tetracyclines. Bacterial resistance to tetracyclines has curtailed their clinical effectiveness. A minimum of semisynthesis and analoging has been carried out with tetracyclines, compared to other classes of antibiotics, perhaps due to their complex chemistry, chemical liability, and lack of reactivity of the intact naphthacene nucleus.

Glyclcyclines, such as tigecycline, recently approved by $\mathrm{FDA}^{20}$, are active against a broad range of Grampositive and Gram-negative bacterial strains resistant to tetracycline or doxycycline. Tigecycline, however, lacks functional groups suitable for connecting to a solid support. Minocycline (MIN), on the other hand, allows exclusive 9-nitration, the starting point for glycylcycline extension.

MIN is effective against a broad range of Gram-positive and Gram-negative bacteria ${ }^{21}$ displaying an MIC of $0.12 \mu \mathrm{g} / \mathrm{mL}$ against $S$. aureus ${ }^{22}$. Against E. faecalis and E. faecium, by comparison, MIN was found $\sim 8$-fold more active than linezolid and 32-fold more than quinupristin-dalfopristin ${ }^{23}$. Bulky groups at the 9position of glycylcyclines usually contribute to activity $^{24}$, supporting our strategy of coupling moieties to the 9-position of MIN to create new glycylcyclines. We therefore chose MIN as the basis for glycylcycline tethering to solid surfaces. 
Here we report the design and synthesis of several MIN C9 derivatives and the determination of their minimum inhibitory concentration (MIC). Attachment of the MIN derivatives to polystyrene beads and Ti6Al4V alloy foils via acid-labile linkers was carried out to characterize the bioactivity of the tethered MIN derivatives.

We synthesized [4S- $(4 \alpha, 12 \mathrm{a} \alpha)]-9-\mathrm{H}_{2} \mathrm{~N}-4,7-b i s\left(\mathrm{Me}_{2} \mathrm{~N}\right)-$ 1,4,4a,5,5a,6,11,12a-octohydro-3,10,12,12a-

tetrahydroxy-1,11-dioxo-2-naphthacenecarboxamide (9$\mathrm{H}_{2} \mathrm{~N}-\mathrm{MIN}$ ) as described ${ }^{22}$. Briefly, to an ice-cold solution of $\mathrm{MIN} \cdot \mathrm{HCl}(1 \mathrm{gram}, 2.03 \mathrm{mmol})$ in $9 \mathrm{~mL}$ of concentrated $\mathrm{H}_{2} \mathrm{SO}_{4}$ was added $\mathrm{KNO}_{3}(224 \mathrm{mg}, 2.4$ $\mathrm{mmol})$. The reaction mixture was stirred at $0^{\circ} \mathrm{C}$ for about 1.5 hour, and monitored by HPLC on a $150 \times 4.6$ $\mathrm{mm}$ Phenomenex ${ }^{\circledR}$ Luna phenyl-hexyl $5 \mu \mathrm{m}$ column, eluted with $25 \% \mathrm{CH}_{3} \mathrm{CN}$ in $35 \mathrm{mM} \mathrm{Na} 2 \underline{\mathrm{HPO}}_{4}, \mathrm{pH} 7.5$, on a Waters 600 liquid chromatograph (Milford MA USA). When the reaction came to completion, the mixture was slowly poured into $240 \mathrm{~mL}$ of ice-cold $\mathrm{Et}_{2} \mathrm{O}$. The precipitate was collected by filtration, and washed with $\mathrm{Et}_{2} \mathrm{O}$ three times. The solid was dried overnight under vacuum to give $9-\mathrm{O}_{2} \mathrm{~N}-\mathrm{MIN} \cdot\left(\mathrm{SO}_{4}\right)_{2}$. The product was characterized by HPLC, showing a prominent product peak, and MS of the main peak (SELDI-TOF mass spectrometer (Ciphergen, Fremont, CA), calc. 502.47 Da, found 502.5 Da. The dried 9$\mathrm{O}_{2} \mathrm{~N}-\mathrm{MIN} \cdot\left(\mathrm{SO}_{4}\right)_{2}(1.29 \mathrm{~g}, 1.8 \mathrm{mmol}), 200 \mathrm{mg}$ of $10 \%$ palladium on charcoal, and $4.5 \mathrm{~mL}$ of $2 \mathrm{~N} \mathrm{H}_{2} \mathrm{SO}_{4}$ in 6 $\mathrm{mL}$ of 2-MeOEtOH were mixed and hydrogenated in a Parr apparatus at $40 \mathrm{psi}$ for $1.5 \mathrm{hr}$. The catalyst was filtered and the filtrate was added dropwise to a mixture of 2-PrOH $(210 \mathrm{~mL})$ and $\mathrm{Et}_{2} \mathrm{O}(150 \mathrm{~mL})$. The yellow solid was collected by filtration, washed several times with $\mathrm{Et}_{2} \mathrm{O}$ and dried under vacuum at room temperature overnight to yield $1.16 \mathrm{~g}$ of $9-\mathrm{H}_{2} \mathrm{~N}-\mathrm{MIN} \cdot\left(\mathrm{SO}_{4}\right)_{2}(90 \%$ yield). The product was characterized by HPLC and MS: calc. 472.2 Da, found 472.0 Da.

We then converted 9- $\mathrm{H}_{2} \mathrm{~N}-\mathrm{MIN}$ into [4S-(4 $\left.\left.\alpha, 12 \mathrm{a} \alpha\right)\right]-9$ [(HNAc)NH]-4,7-bis $\left(\mathrm{Me}_{2} \mathrm{~N}\right)-1,4,4 \mathrm{a}, 5,5 \mathrm{a}, 6,11,12 \mathrm{a}-$ octohydro-3,10,12,12a-tetrahydroxy-1,11-dioxo-2naphthacenecarboxamide (9-Gly-NH-MIN). To a solution of Boc-Gly (458 mg, $1.2 \mathrm{mmol}$ ) in $3 \mathrm{~mL}$ $\mathrm{Me}_{2} \mathrm{NCHO}$ was added $412 \mathrm{mg}$ of $2-(7-a z a-1 \mathrm{H}-$ benzotriazole-1-yl)-1,1,3,3-tetramethyl-uronium hexafluorophosphate (HATU) (Applied Biosystems, Foster City CA, USA) (1.1 equivalent) and $311 \mu \mathrm{L}$ of $\mathrm{iPr}_{2} \mathrm{EtN}$. The reaction mixture was stirred at room temperature for $30 \mathrm{~min}$, then mixed with $9-\mathrm{H}_{2} \mathrm{~N}-\mathrm{MIN} \cdot\left(\mathrm{SO}_{4}\right)_{2}(575$ $\mathrm{mg}, 0.95 \mathrm{mmol}$ ) in $4 \mathrm{~mL} \mathrm{Me} \mathrm{MCHO}_{2} \mathrm{NCH}$. After $1 \mathrm{hr}$ at room temperature, the product was precipitated by addition of 2 volumes of ice-cold $\mathrm{Et}_{2} \mathrm{O}$. After sedimentation and removal of supernatant, the precipitate was dissolved in $4 \mathrm{~N} \mathrm{HCl} /$ dioxane and incubated for $10 \mathrm{~min}$. at room temperature to remove the Boc protecting group. The final product, 9-Gly- $\mathrm{H}_{2} \mathrm{~N}-\mathrm{MIN}$, was precipitated twice from $\mathrm{Et}_{2} \mathrm{O}$ ). MS: calc. $529.54 \mathrm{Da}$, found 530.1 Da.
Next, we prepared [4S- $(4 \alpha, 12 \mathrm{a} \alpha)]-4,7-\mathrm{Bis}\left(\mathrm{Me}_{2} \mathrm{~N}\right)-9$ [(HNAc)NH]-4,7-bis $\left(\mathrm{Me}_{2} \mathrm{~N}\right)-1,4,4 \mathrm{a}, 5,5 \mathrm{a}, 6,11,12 \mathrm{a}-$

octohydro-3,10,12,12a-tetrahydroxy-1,11-dioxo-2-

naphthacenecarboxamide (9-hydrazino-Ac- $\mathrm{H}_{2} \mathrm{~N}-\mathrm{MIN}$ ) (Scheme 1). To a solution of N,N,N'-Boc $3^{-}$ hydrazinoacetic acid (369 mg, $0.95 \mathrm{mmol})$ in $3 \mathrm{~mL}$ $\mathrm{Me}_{2} \mathrm{NCHO}$ was added $397 \mathrm{mg}$ of HATU (1.1 equivalent) and $264 \mu \mathrm{l}$ of $\mathrm{iPr}_{2} \mathrm{EtN}$. The reaction mixture was stirred at room temperature for $30 \mathrm{~min}$, then mixed with $9-\mathrm{H}_{2} \mathrm{~N}-\mathrm{MIN} \cdot\left(\mathrm{SO}_{4}\right)_{2}(600 \mathrm{mg}, 0.9 \mathrm{mmol})$ in $4 \mathrm{~mL}$ $\mathrm{Me}_{2} \mathrm{NCHO}$ and $1 \mathrm{~g}$ of $\mathrm{NaCO}_{3}$, and stirred for $1 \mathrm{hr}$ at room temperature. It was found that the yellow solution changed to brown. The solid was removed by filtration and the filtrate was applied to a $150 \times 15 \mathrm{~mm} \mathrm{C}_{18}$ column (WAT 020594, Waters Associates). The column was washed with $\mathrm{H}_{2} \mathrm{O}$ to remove $\mathrm{Me}_{2} \mathrm{NCHO}$. Because of the strong hydrophobicity of 9-Boc 3 -hydrazino-Ac-NHMIN, the impurities in the reaction mixture could be eluted from the $\mathrm{C}_{18}$ column by $20 \% \mathrm{CH}_{3} \mathrm{CN}$ in aqueous $0.1 \% \mathrm{CF}_{3} \mathrm{CO}_{2} \mathrm{H}$. The product was eluted with pure $\mathrm{CH}_{3} \mathrm{CN}$, concentrated by rotatory evaporation, and lyophilized overnight. The dried sample was dissolved in $4 \mathrm{M} \mathrm{HCl}$ in dioxane to deprotect the Boc groups. After $10 \mathrm{~min}$, a precipitate was formed. The mixture was kept at room temperature under shaking. The precipitate was collected by filtration and washed with $\mathrm{Et}_{2} \mathrm{O}$ three times. The solid product was dried under vacuum to give $510 \mathrm{mg}$ of 9-hydrazino-Ac- $\mathrm{H}_{2} \mathrm{~N}-\mathrm{MIN}$ $\cdot(\mathrm{Cl})_{2}$ as a yellow powder (92\% yield). The product was characterized by HPLC and MS: calc. $544.56 \mathrm{Da}$, found 544.6 Da.

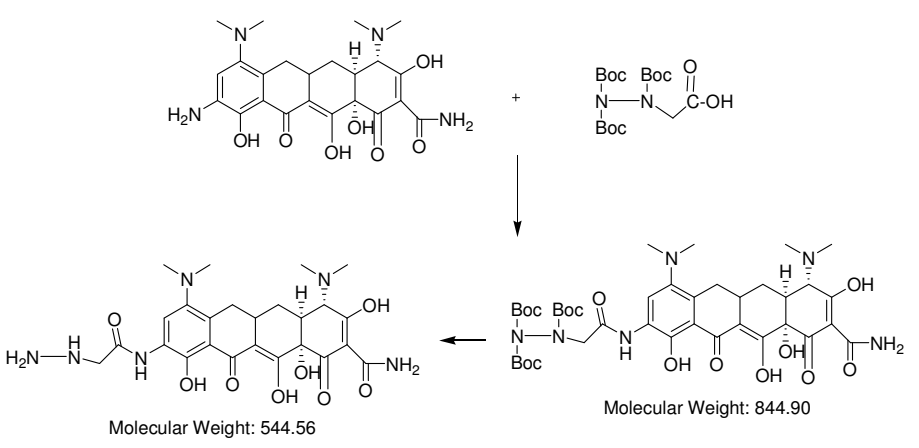

Scheme 1. Reaction scheme for synthesis of 9-hydrazino-Ac-NH-MIN.

To PEGylate 9-Gly-NH-MIN, we added 1 equivalent of HATU and 1.2 equivalent of $\mathrm{iPr}_{2} \mathrm{EtN}$ to $1 \mathrm{~mL}$ $\mathrm{Me}_{2} \mathrm{NCHO}$ containing $100 \mathrm{mg}$ of O-(N-Fmoc-2aminoethyl)-O`-(2-carboxyethyl)-undecaethyleneglycol $\left(\mathrm{PEG}_{12}\right.$ carboxylate) (Merck, Darmstadt, Germany) stirred at room temperature for $30 \mathrm{~min}$, to which 1.1 equivalent of 9-Gly-NH-MIN was added. The reaction mixture was kept at room temperature for $2 \mathrm{hr}$ under stirring. The reaction was stopped by addition of $\mathrm{H}_{2} \mathrm{O}$. Taking the molecular mass (1351 Da) of 9- $\mathrm{PEG}_{12}-\mathrm{Gly}-$ NH-MIN into consideration, we employed a Sephadex G-25 column $(1.7 \times 30 \mathrm{~cm})$ eluted with aqueous $0.5 \%$ HOAc to separate the conjugate from the impurities. The eluent corresponding to the first peak was collected, 
concentrated and freeze dried. The dried sample was redissolved in $\mathrm{H}_{2} \mathrm{O}$, then characterized by HPLC and MS: calc. 1351.49 Da, found 1351.6 Da. 9-PEG ${ }_{26}$-GlyNH-MIN was prepared similarly. The product was characterized by HPLC and MS: calc. 2056.33 Da, found 2056.0 Da.

Measurements of $\mathrm{MIC}^{25}$ for each of the MIN derivatives without PEG (Table 1) showed that 9-Gly-NH-MIN and 9-hydrazino-Ac-NH-MIN retained significant biological activity, compared with unmodified MIN. However, the MIC of the two 9-PEG-MIN derivatives was dramatically elevated. The bulky PEG modification might have inhibited bacterial uptake of the MIN derivatives, and/or the binding of MIN to the $30 \mathrm{~S}$ ribosomal subunits, resulting in the loss of bioactivity by the PEG-MIN derivatives. This result argues against permanent PEG tethering of MIN derivatives to medical implants.

\begin{tabular}{|c|c|c|}
\hline \multicolumn{3}{|c|}{ Table 1. MIC of MIN derivatives with $S$. aureus } \\
\hline Compound & $\begin{array}{l}\text { MIC } \\
\text { (found) } \\
\mu \mathrm{g} / \mathrm{mL}\end{array}$ & $\begin{array}{c}\text { MIC } \\
\text { (published) } \\
\mu \mathrm{g} / \mathrm{mL}\end{array}$ \\
\hline MIN & 0.125 & 0.125 \\
\hline $9-\mathrm{H}_{2} \mathrm{~N}-\mathrm{MIN}$ & 2 & 1 \\
\hline 9-Gly-NH-MIN & 2 & $0.5-1$ \\
\hline 9-hydrazino-Ac-NH-MIN & 2 & NA \\
\hline 9-PEG ${ }_{12}$-Gly-NH-MIN & 500 & NA \\
\hline 9-PEG 26 -Gly-NH-MIN & 1000 & NA \\
\hline
\end{tabular}

S. aureus subspecies aureus Rosenbach (ATCC 25923) were incubated in Mueller-Hinton broth at $37^{\circ} \mathrm{C}$ for 14 $\mathrm{hr}$, noting the dilution midway between fully inhibited and uninhibited bacterial proliferation ${ }^{25}$

Because of the loss of bioactivity of MIN after conjugation with PEG, we selected the acid-liable hydrazone bond to link 9-hydrazino-Ac-NH-MIN to solid surfaces, so that the drug could be released on demand upon acidification of the microenvironment by proliferating bacteria ${ }^{26}$.

Hydrazone bonds have been widely investigated for targeting drug delivery ${ }^{27}$. The bond is relatively stable in physiological $\mathrm{pH}$. When the delivered drug was absorbed through endocytosis pathway, the hydrazone could be broken in response to the low $\mathrm{pH}$ in cytoplasmic endosomes $^{28}$. To enable release on demand, the hydrazone bonds should remain largely intact for an effective number of days after implant insertion. For the attachment of antibiotics to the surface of implants by

acid-labile linkers, we expect that the antibiotics should remain stably attached on the surface for weeks to months. Due to the reversible property of hydrazone bonds in aqueous solution, the antibiotics attached to implant surfaces could be released gradually at neutral $\mathrm{pH}$, but rapidly at acid $\mathrm{pH}$ induced by infection.
We selected TentaGel S-NH polystyrene beads as a model to investigate the release of 9-hydrazino-Ac-NHMIN from a polymeric surface. The amino groups on

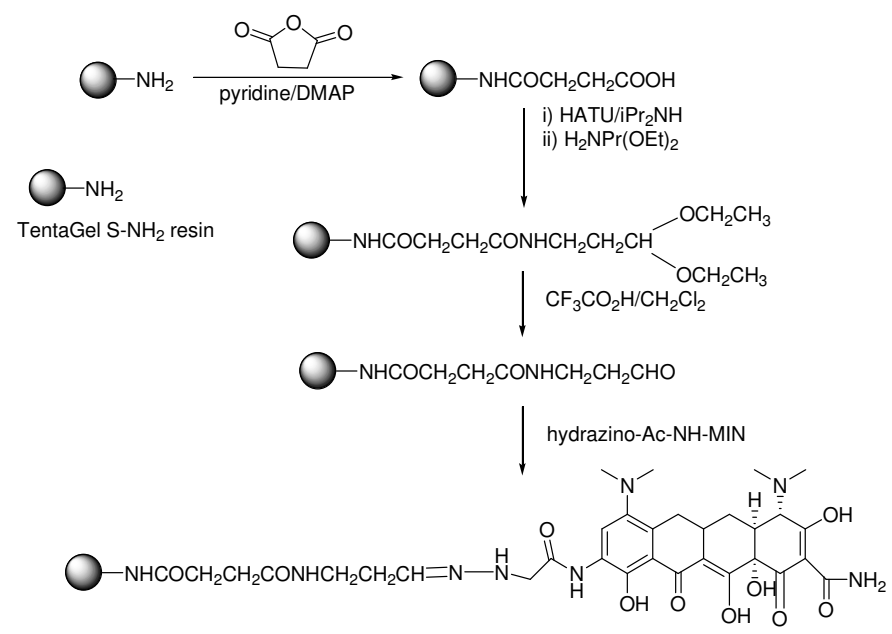

Scheme 2. Reaction scheme for synthesis of PS-Succ-NHPr-hydrazone-9Ac-NH-MIN.

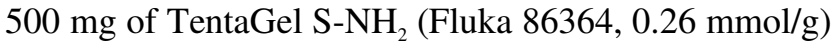
resin were transformed to carboxylates by reaction with 1.5 equivalent of succinic anhydride in the presence of 0.1 equivalent of $\mathrm{N}, \mathrm{N}$-dimethylaminopyridine (DMAP) catalyst dissolved in in $4 \mathrm{~mL}$ of pyridine (Scheme 2). The reaction mixture was kept at $50^{\circ} \mathrm{C}$ with shaking for $3 \mathrm{hr}$. A ninhydrin test showed no free amino groups available on the surface of the resin beads. The carboxylates on the resin were activated by HATU and ${ }_{i P r}{ }_{2} \mathrm{EtN}$ at room temperature for $30 \mathrm{~min}$, then coupled with $\mathrm{H}_{2} \mathrm{NPr}(\mathrm{OEt})_{2}$ at room temperature for $3 \mathrm{hr}$. The resin was washed with $\mathrm{Me}_{2} \mathrm{NCHO}$ and $\mathrm{CH}_{2} \mathrm{Cl}_{2}$, then dried under vacuum. Next, the resin was treated with $50 \% \mathrm{CF}_{3} \mathrm{CO}_{2} \mathrm{H}$ in $\mathrm{CH}_{2} \mathrm{Cl}_{2}$ for $30 \mathrm{~min}$ to yield aldehydemodified resin, which was washed with $\mathrm{Me}_{2} \mathrm{NCHO}$ and $\mathrm{CH}_{2} \mathrm{Cl}_{2}$, then dried under vacuum overnight. 9Hydrazino-Ac-NH-MIN at $0.1 \mathrm{M}$ in $\mathrm{CHCl}_{3}$ was then reacted with the aldehyde termini to yield the acid-labile hydrazone-linked 9-Ac-NH-MIN polystyrene beads. The resin was washed with physiological buffer $(0.15 \mathrm{M}$ $\left.\mathrm{NaCl}, 0.01 \mathrm{M} \mathrm{Na}_{2} \mathrm{HPO}_{4}, \mathrm{pH} 7.4, \mathrm{PBS}\right), \mathrm{Me}_{2} \mathrm{NCHO}$ and $\mathrm{CH}_{2} \mathrm{Cl}_{2}$, then dried under vacuum overnight. PS-SuccNHPr-hydrazone-9-Ac-NH-MIN resin beads were stripped with $10 \% \mathrm{HOAc}$ in $\mathrm{CH}_{2} \mathrm{Cl}_{2}$ to determine the total loading of 9-hydrazino-Ac-NH-MIN， $52 \mu \mathrm{g} / \mathrm{g}$ resin, by absorbance at $350 \mathrm{~nm}^{29}$.

The stability of the hydrazone bond was investigated by incubating $5.6 \mathrm{mg}$ aliquots of PS-Succ-NHPrhydrazone-9-Ac-NH-MIN resin beads at $37^{\circ} \mathrm{C}$ under physiological conditions in $1.5 \mathrm{~mL}$ of $0.1 \mathrm{M} \mathrm{Na}_{2} \mathrm{HPO}_{4}$, $\mathrm{pH}$ 7.4, and under conditions of anaerobic bacterial metabolism in a confined microenvironment in $0.1 \mathrm{M}$ $\mathrm{NaOAc}, \mathrm{pH}$ 5.0. The concentration of the released 9hydrazino-Ac-NH-MIN in the buffers was determined by absorbance at $350 \mathrm{~nm}^{29}$ (Fig. 1). 


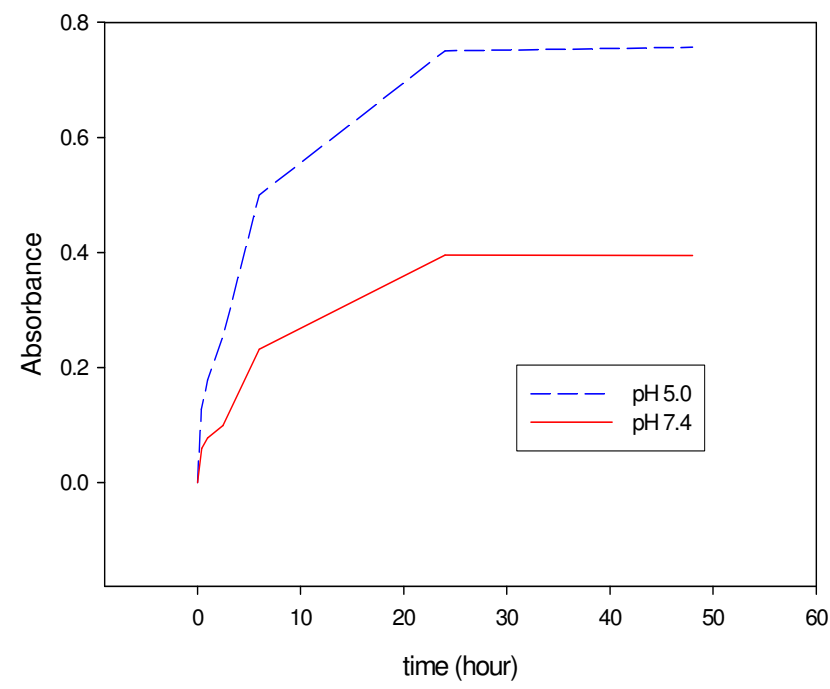

Figure. 1. Release of 9-hydrazino-Ac-NH-MIN from PS-Succ-NHPrhydrazone-9-Ac-NH-MIN resin beads as a function of $\mathrm{pH}$. Solid line: 0.1

$\mathrm{M} \mathrm{Na}_{2} \underline{\mathrm{HPO}_{4}}, \mathrm{pH}$ 7.4. Dashed line: $0.1 \mathrm{M} \mathrm{NaOAc}, \mathrm{pH}$ 5.0.

The time course of 9-hydrazino-Ac-NH-MIN release from the beads showed much faster release at $\mathrm{pH} 5.0$ than at $\mathrm{pH}$ 7.4. After $24 \mathrm{hr}$ at $\mathrm{pH} 5.0$, released MIN reached $36.7 \mu \mathrm{g} / \mathrm{mL}$, or $54 \%$ of the MIN loading measured after coupling (Fig. 1). That value is 18 times greater than the MIC of $2 \mu \mathrm{g} / \mathrm{mL}$. After $24 \mathrm{hr}$ at $\mathrm{pH} 7.4$, released MIN reached $18.8 \mu \mathrm{g} / \mathrm{mL}$, or $27.6 \%$ of the MIN loading measured after coupling The leveling of the $\mathrm{A}_{350}$ trace after $24 \mathrm{hr}$ is probably the result of the instability of hydrazino-MIN. Hence, the hydrazone bond is not stable enough to keep 9-hydrazino-Ac-NHMIN on the surface for an extended period of time.

We also attached 9-hydrazino-Ac-NH-MIN to the surface of Ti6Al4V foil. We prepared $\mathrm{H}_{2} \mathrm{NPrSi}-\mathrm{O}$ Ti6A14V alloy foil as described previously for Ti6Al4V pins $^{17}$. The amine was then coupled with 4 equivalents of glyoxylyl-8-amino-3,5-dioxaoctanoic acid in the presence of $\mathrm{HATU} / \mathrm{Pr}_{2} \mathrm{EtN}$ in $\mathrm{Me}_{2} \mathrm{NCHO}$. 9Hydrazino-Ac-NH-MIN at $0.1 \mathrm{M}$ in $\mathrm{CHCl}_{3}$ was coupled to the surface of the aldehyde-PEG-NHPrSi-O-Ti6Al4V foil for $4 \mathrm{hr}$ to yield Ti-O-SiPrNH-PEG-hydrazone-9Ac-NH-MIN. The foil was washed with $\mathrm{CH}_{2} \mathrm{Cl}_{2}$, $\mathrm{Me}_{2} \mathrm{NCHO}$ and double deionized $\mathrm{H}_{2} \mathrm{O}$, then dried under vacuum overnight. On the surface of a one $\mathrm{cm}^{2}$ Ti6Al4V foil with a maximum monolayer loading of $200 \mathrm{pmol}^{30}$, as we found for $\mathrm{VAN}^{18}$, the amount of strippable MIN would be too low to measure by UV absorbance.

To determine bacterial viability on Ti6Al4V foil substrates, control Ti6Al4V alloy foils and Ti-OSiPrNH-PEG-hydrazone-9-Ac-NH-MIN alloy foils were sterilized by incubation with $70 \% \mathrm{EtOH}$, and washed five times with autoclaved PBS. S. aureus subspecies aureus Rosenbach were cultured in MuellerHinton broth at $250 \mathrm{rpm}, 37^{\circ} \mathrm{C}$ for $14 \mathrm{hr}$. Using a 0.5 McFarland standard, the bacteria were diluted to $1 \times 10^{4}$ $\mathrm{cfu} / \mathrm{mL}$ in Mueller-Hinton broth. The sterilized
Ti6Al4V foils were cultured with the $S$. aureus at $37^{\circ} \mathrm{C}$ for $24 \mathrm{hr}$, after which the $\mathrm{pH}$ was still 7.3-7.4. For Ti6Al4V foil, we immersed the MIN-bonded foil in the minimum volume of $200 \mu \mathrm{L}$ of broth. The foils were washed three times with PBS to remove loosely adherent bacteria, and assessed for bacterial adhesion and viability by staining with the Live/Dead® BacLight $^{\mathrm{TM}}$ viability kit, which fluorescently labels viable bacteria green and dead bacteria red. After labeling, the Ti6Al4V alloy foils were washed three times with PBS to remove nonspecific stain and visualized by confocal laser fluorescence microscope on a Fluoview 300 (Olympus, Melville, NY). Challenge by $S$. aureus, however, showed live bacteria on all foil samples. At physiological $\mathrm{pH}$, the concentration of 9hydrazino-Ac-NH-MIN that could be released into the medium was insufficient to inhibit the growth of $S$. aureus. Even if all the attached monolayer of MIN were released into the broth, the resulting MIN concentration of $1.2 \mu \mathrm{g} / \mathrm{mL}$ would have been below the MIC of 2 $\mu \mathrm{g} / \mathrm{mL}$. The flat foil has much less surface area than the porous resin beads.

For the construction of medical implants with covalently bound broad-spectrum antibiotics for selfprotection against Gram-negative colonization, we designed and synthesized three MIN derivatives. Conjugation of long hydrophilic PEG spacers with MIN at the C9 position resulted in dramatic loss of bioactivity, which argued against the utility of permanent linkage of MIN to the surface of medical implants by PEG spacers.

Knowing that 9-hydrazino-Ac-NH-MIN showed reasonable antibiotic activity, we attached it to the surfaces of polystyrene beads and Ti6Al4V foils by an acid-labile hydrazone bond that would permit release of free 9-hydrazino-Ac-NH-MIN to enter bacteria, triggered by bacterial acidification of the implant microenvironment. The release kinetics showed a clear difference between the rates of 9-hydrazino-Ac-NHMIN released at $\mathrm{pH} 7.4$ and $\mathrm{pH}$ 5.0. However, the hydrazone bond may not be stable enough for long term medical implant application. We are also considering methylmaleimide ${ }^{31}$ linkers to enable this strategy.

We thank Dr. Richard Wassell for assistance with mass spectroscopy. This work was supported in part by DoD grant DAMD-17-03-1-0713.

(1)Toubes, E.; Segreti, J. Curr Infect Dis Rep 2002, 4, 433-438.

(2)Garvin, K. L.; Hanssen, A. D. J. Bone Joint Surg. 1995, 77A, 1576-1588.

(3)Duggan, J. M.; Georgiadis, G. M.; Kleshinski, J. F. Infect. Med. 2001, 18, 534-541.

(4)Zimmerli, W.; Trampuz, A.; Ochsner, P. E. N Engl J Med 2004, 351, 1645-54.

(5)Haddad, F. S.; Masri, B. A.; Campbell, D.; 
McGraw, R. W.; Beauchamp, C. P.; Duncan, C. P. Journal of Bone \& Joint Surgery - British Volume 2000, 82, 80712.

(6)Loll, P. J.; Axelsen, P. H. Annual Review of Biophysics \& Biomolecular Structure. 2000, 29, 265-89.

(7)van de Belt, H.; Neut, D.; Schenk, W.; van Horn, J. R.; van der Mei, H. C.; Busscher, H. J. Acta Orthopaedica Scandinavica. 2001, 72, 557-71.

(8)Frazier, D. D.; Lathi, V. K.; Gerhart, T. N.; Hayes, W. C. Journal of Biomedical Materials Research 1997, 35, 383-9.

(9)Montali, A. Injury 2006, 37 Suppl 2, S81-6.

(10)Liu, X.; Chu, P. K.; Ding, C. Materials Science and Engineering R: Reports 2004, 47, 49-121.

(11)Jose, B.; Antoci, J., V.; Zeiger, A. R.; Wickstrom, E.; Hickok, N. J. Chemistry \& Biology 2005, 12, 10411048.

(12)Puleo, D. A.; Kissling, R. A.; Sheu, M. S. Biomaterials 2002, 23, 2079-87.

(13)Jennissen, H. P. Ann N Y Acad Sci 2002, 961, 13942 .

(14)Walsh, C. Nature 2000, 406, 775-81.

(15)Kahne, D.; Leimkuhler, C.; Lu, W.; Walsh, C. Chem Rev 2005, 105, 425-48.

(16)Zreiqat, H.; Akin, F. A.; Howlett, C. R.; Markovic, B.; Haynes, D.; Lateef, S.; Hanley, L. J Biomed Mater Res A 2003, 64, 105-13.

(17)Edupuganti, O. P.; Antoci, V., Jr.; King, S. B.; Jose, B.; Adams, C. S.; Parvizi, J.; Shapiro, I. M.; Zeiger, A. R.; Hickok, N. J.; Wickstrom, E. Bioorganic \& Medicinal Chemistry Letters 2007, 17, 2692-2696.

(18)Antoci, V., Jr.; King, S. B.; Jose, B.; Parvizi, J.; Zeiger, A. R.; Wickstrom, E.; Freeman, T. A.; Composto, R. J.; Ducheyne, P.; Shapiro, I. M.; Hickok, N. J.; Adams, C. S. Journal of Orthopaedic Research 2007, 25, 858-866.

(19)Schierholz, J. M.; Beuth, J. Journal of Hospital Infection. 2001, 49, 87-93.

(20)van Ogtrop, M. L.; Andes, D.; Stamstad, T. J.; Conklin, B.; Weiss, W. J.; Craig, W. A.; Vesga, O. Antimicrob Agents Chemother 2000, 44, 943-9.

(21)Zhanel, G. G.; Homenuik, K.; Nichol, K.; Noreddin, A.; Vercaigne, L.; Embil, J.; Gin, A.; Karlowsky, J. A.; Hoban, D. J. Drugs 2004, 64, 63-88.

(22)Sum, P. E.; Lee, V. J.; Testa, R. T.; Hlavka, J. J.; Ellestad, G. A.; Bloom, J. D.; Gluzman, Y.; Tally, F. P. J Med Chem 1994, 37, 184-8.

(23)Milatovic, D.; Schmitz, F. J.; Verhoef, J.; Fluit, A. C. Antimicrob Agents Chemother 2003, 47, 400-4.

(24)Barden, T. C.; Buckwalter, B. L.; Testa, R. T.; Petersen, P. J.; Lee, V. J. J Med Chem 1994, 37, 3205-11.

(25)NCCLS Methods for Dilution Antimicrobial Susceptibility Tests for Bacteria That Grow Aerobically; Approved Standard; 5th ed.; National Committee of Clinical Laboratory Standards: Wayne PA, 2000; Vol. NCCLS document M7-A5.

(26)DeLand, F.; Wagner, H. N., Jr. J Lab Clin Med
1970, 75, 529-34.

(27)Ulbrich, K.; Subr, V. Adv Drug Deliv Rev 2004, $56,1023-50$. 60.

(28)Van Dyke, R. W. Subcell Biochem 1996, 27, 331-

(29)Hasan, T.; Khan, A. U. Proc Natl Acad Sci U S A 1986, 83, 4604-6.

(30)Puleo, D. A. Journal of Biomedical Materials Research 1997, 37, 222-228.

(31)Drummond, D. C.; Daleke, D. L. Chem Phys Lipids 1995, 75, 27-41. 